\title{
REVIEW OF THE GENUS GYMNOPETALUM (CUCURBITACEAE)
}

\author{
W.J.J.O. DE WILDE \& B.E.E. DUYFJES \\ Nationaal Herbarium Nederland, Universiteit Leiden branch, P.O. Box 9514, \\ 2300 RA Leiden, The Netherlands; e-mail: dewilde@nhn.leidenuniv.nl
}

\begin{abstract}
SUMMARY
Gymnopetalum Arn. is distributed from India to the Moluccas. There are 4 species, including 1 new species, G. orientale W.J. de Wilde \& Duyfjes, from E Malesia. In G. integrifolium (Roxb.) Kurtz 2 new varieties, besides the type-variety, are accepted: G. integrifolium var. penicaudii (Gagnep.) W.J. de Wilde \& Duyfjes (in China) and G. integrifolium var. pectinatum W.J. de Wilde \& Duyfjes (in E Java). A key to the species is presented. The Malesian taxa are fully described.
\end{abstract}

Key words: Gymnopetalum, Cucurbitaceae, SE Asia.

\section{INTRODUCTION}

Since the revisions of the genus Trichosanthes in the Malesian area and Thailand (Rugayah \& De Wilde, 1997, 1999; Rugayah, 1999; De Wilde \& Duyfjes, 2004; Duyfjes \& Pruesapan, 2004) some poorly collected specimens from E Malesia and assigned to that genus remained undetermined. More recently collected material appeared identical with these specimens by which it became clear that they represented a new species of Gymnopetalum, G. orientale. In the genus Gymnopetalum, which is taxonomically close to Trichosanthes, 4 species are now recognized. The type-species of the genus is G. tubiflorum, from S India and Sri Lanka; the other 3 species are distributed in SE Asia and Malesia. Two aberrant collections from E Java are included in the widespread G. integrifolium as a new variety, var. pectinatum. Plants from China (Hainan) of $G$. integrifolium with strongly dentate leaves are recognized as var. penicaudii.

Cogniaux (1881) and Cogniaux \& Harms (1924) placed G. tubiflorum in section Eugymnopetalum and the other species in the section Tripodanthera. Although G. tubiflorum, which is possibly tuberous and has more slender shoots, is rather isolated from the other 3 species, we follow more recent authors (Jeffrey, 1980b; Philcox, 1997) in not maintaining the sections.

The new species $G$. orientale deceptively resembles certain members of Trichosanthes, for instance by the presence of a sometimes conspicuous probract on the node, which could be regarded as intermediate between the two genera. A useful and practical floral distinction between both genera, besides the presence or absence of thread-like fringes of the petals (fringed in Trichosanthes), is the overall shape of the folded petals in mature bud: short and rounded in Trichosanthes and elongate, longer than broad, in Gymnopetalum. 
Three genera from northern India resemble Gymnopetalum on first sight. They are: Edgaria C.B. Clarke (differing by straight thecae and few seeds), Biswarea Cogn. and Herpetospermum Wall. (the latter two differing by petals connate at the bases and \pm 3 -valved fruits).

\section{GYMNOPETALUM}

Gymnopetalum Arn. (1840) 52; (1841) 278; Endl. (1842) 77; M. Roem. (1846) 17; Miq. (1856) 679; Benth. \& Hook.f. (1867) 822; Kurz (1877) 99; C. B. Clarke (1879) 611; Cogn. (1881) 387; Trimen (1894) 246; Gagnep. (1921) 1048; Cogn. \& Harms (1924) 177; Chakrav. (1959) 56; Backer (1964) 302; Keraudren (1975) 96; C. Jeffrey (1980a) 52; (1980b) 798; A.M. Lu \& Zhi Y. Zhang (1986) 212; S.K. Chen (1995) 345; Philcox (1997) 14. - Lectotype species (Keraudren, 1975): Gymnopetalum ceylonicum Arn., nom. illeg. = Gymnopetalum tubiflorum (Wight \& Arn.) Cogn.

Tripodanthera M. Roem. (1846) 48.

Scotanthus Naudin (1862) 172.

Annual or perennial, climbing or widely-creeping herbs, to $6 \mathrm{~m}$ long, frequently rooting at the nodes, subglabrous to densely hairy; monoecious (or seemingly dioecious). Probract present or absent. Tendrils simple or 2-branched. Leaves simple, entire or lobed, base deeply cordate, margin finely dentate; glands not obvious. Inflorescences in male: flowers either solitary (or 2) on the nodes, long-pedicelled, or (co-axillary) in an erect several-flowered bracteate raceme, with flowers sessile or short-pedicelled; in female: flowers solitary. Flowers: petals white, in bud folded into an elongate body. Male flowers: receptacle elongate, broadened in upper half and slightly constricted at the throat; sepals 5, free; petals (almost) free, margin entire or short-fimbriate; stamens 3 , filaments inserted about halfway up the receptacle-tube, free, short; anthers two 2-thecous, one 1-thecous, thecae sigmoid, united into an elongate synandrium, included; disc or pistillode absent or present, small, as 3 linear ribs, adnate to the base of the tube. Female flowers: ovary with many horizontal ovules; perianth as in male flowers; style long, stigmas 3, oblong or linear; disc not obvious; staminodes minute. Fruits orange or red, mesocarp yellow, pulp greenish-black. Seeds numerous, compressed, not or little ornamented.

A genus of 4 species: one species in S India and Sri Lanka; 3 in N India, S China, east to E Malesia; 2 in Thailand, and 3 in the Malesian area. The genus is rare in regions with an ever-wet climate.

\section{KEY TO THE SPECIES OF GYMNOPETALUM}

1a. Plant tuberous, perennial; shoots delicate; stem c. $1 \mathrm{~mm}$ diameter. Male raceme slender, bracts linear, small. Petals c. $10 \mathrm{~mm}$ long. Seeds truncate at one end. S India, Sri Lanka . . . . . . . . . . . . . . . . 4. G. tubiflorum

b. Plant without tuber, (sub)annual; shoots stouter, stem c. $2 \mathrm{~mm}$ diameter. Male raceme stouter (rachis c. $2 \mathrm{~mm}$ diameter), bracts leaf-like, variously lobed. Petals 20-30 mm long. Seeds rounded at both ends . . . . . . . . . . . 2

2a. Leaves finely bullate, densely hairy below, at least on the veins. Fruits ellipsoid or globose, rounded at apex, not ribbed. - Widespread . . . . 2. G. integrifolium

b. Leaves not bullate, thinly hairy or subglabrous below. Fruits ellipsoid-fusiform, narrowed at apex, distinctly or faintly ribbed, or not ribbed ........ 3 
3a. Male bracts cuneate or rounded at base, sessile, without glands. Sepals entire or rarely \pm lobed. Male flowers in raceme pedicellate, pedicels persistent. Fruits dis-

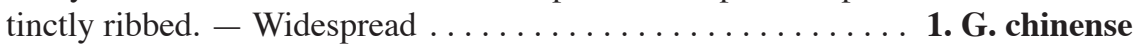

b. Male bracts narrowly cuneate at base, subsessile or short-stipitate, with scattered glands below. Sepals deeply lobed. Male flowers in raceme sessile, without pedicels. Fruits not or faintly ribbed. - E Malesia . . . . . . . . . . 3. G. orientale

\section{Gymnopetalum chinense (Lour.) Merr. - Fig. 1b, 2}

Gymnopetalum chinense (Lour.) Merr. (1919) 256; Jeffrey (1980a) 52; A.M. Lu \& Zhi Y. Zhang (1986) 213, f. 55: 1-7; S.K. Chen (1995) 345, f. 90: 1-5. - Evonymus chinensis Lour. (1790) 156. - Type: Loureiro †; lectotype, according to Merrill (1919), preferably to be chosen from Levine 1108, 1705, or 2183 from Canton (all PNH), but we do not know whether any of this material still exists.

Bryonia cochinchinensis Lour. (1790) 595. - Tripodanthera cochinchinensis (Lour.) M. Roem. (1846) 48. - Gymnopetalum cochinchinense (Lour.) Kurz (1871a) 57; (1871b) 295; Cogn. (1881) 391; Gagnep. (1921) 1049; Cogn. \& Harms (1924) 181; Craib (1931) 755; Merr. (1935) 379; Chakrav. (1959) 62; Backer (1964) 302; Keraudren (1975) 97, f. 17: 4-8; C. Jeffrey (1980b) 798; P.H. Hô (1991) 722, f. 2002. - Type: Loureiro s.n. (BM), Vietnam.

Momordica tubiflora Roxb. (1814) 70, nom. nud.; (1832) 711; (1978) f. 15; G. Don (1834) 36. - Scotanthus tubiflorus (Roxb.) Naudin (1862) 172, f. 3. - Type: Wallich Cat. 6749 (K-W), India.

Trichosanthes costata Blume (1826) 933. - Lectotype (here chosen): Blume s.n. barcode L0589632, (L; 2 isotypes in L), Java.

Gymnopetalum quinquelobum Miq. (1856) 681. - Type: Horsfield s.n. (not seen), Java (Soerakarta).

Scotanthus porteanus Naudin (1866) 25. - Type: Cultivated in Huber's botanic garden from seeds from Singapore (P, not seen).

Gymnopetalum heterophyllum Kurz (1875) 326. - Type: Wallich Cat. 6711 (K-W, not seen); Wall. Cat. 6711 consists in the IDC photos of apparently 5 sheets; it is a mixture with a.o. Coccinia grandis, but $6711-E$ is missing.

Trichosanthes laciniata Ridl. (1911) 107. - Type: Curtis in Ridley 8350 (K, not seen), Malaysia, Langkawi.

Melothria touchanensis H. Lév. (1914) 122. - Type: Bodinier s.n. (E), China, Kweichau.

Gymnopetalum cochinchinense (Lour.) Kurz var. incisa Gagnep. (1921) 1050; P.H. Hô (1991) 722, f. 2003. - Lectotype (here chosen): Lecomte \& Finet s.n. (P), Cambodia.

Gymnopetalum quinquelobatum Merr. (1938) 70. - Type: Squires 943 (not seen), southern Annam, near Dalat.

Climbing or creeping, rooting at the nodes, to $6 \mathrm{~m}$ long, finely scabrous and sparsely hairy or subglabrous; monoecious. Leaves: blade membranous, in outline ovate, or triangular, or \pm 3 - or 5-angled or (deeply) lobed, 4-12 cm diam., base deeply cordate, apex acute(-acuminate), margin finely sparsely dentate, blade \pm sparsely scabrouspubescent on both surfaces, upper surface not bullate, main nerves 5, subpalmate; glands absent; cystoliths usually faint, or fine; petiole $2-5 \mathrm{~cm}$. Probract (minute, caducous or) absent. Tendrils simple. Male flowers: solitary or in erect racemes $10-25 \mathrm{~cm}$ long, bracteate, several-flowered, sometimes co-axillary with a solitary flower; peduncle 4-12 cm long; bracts oblong, 15-20 mm long, (deeply) 2-5-lobed, base cuneate or rounded, sessile, without glands; flowers thinly grey pubescent; pedicel 3-7 cm long for solitary flowers, $5-15 \mathrm{~mm}$ long in the racemes, faintly articulate with receptacle; receptacle-tube narrow, but widened in upper $1 / 3$ where containing the synandrium, 25-35 mm long, 3-4(-5) $\mathrm{mm}$ wide at throat, outside and inside \pm pubescent, throat 


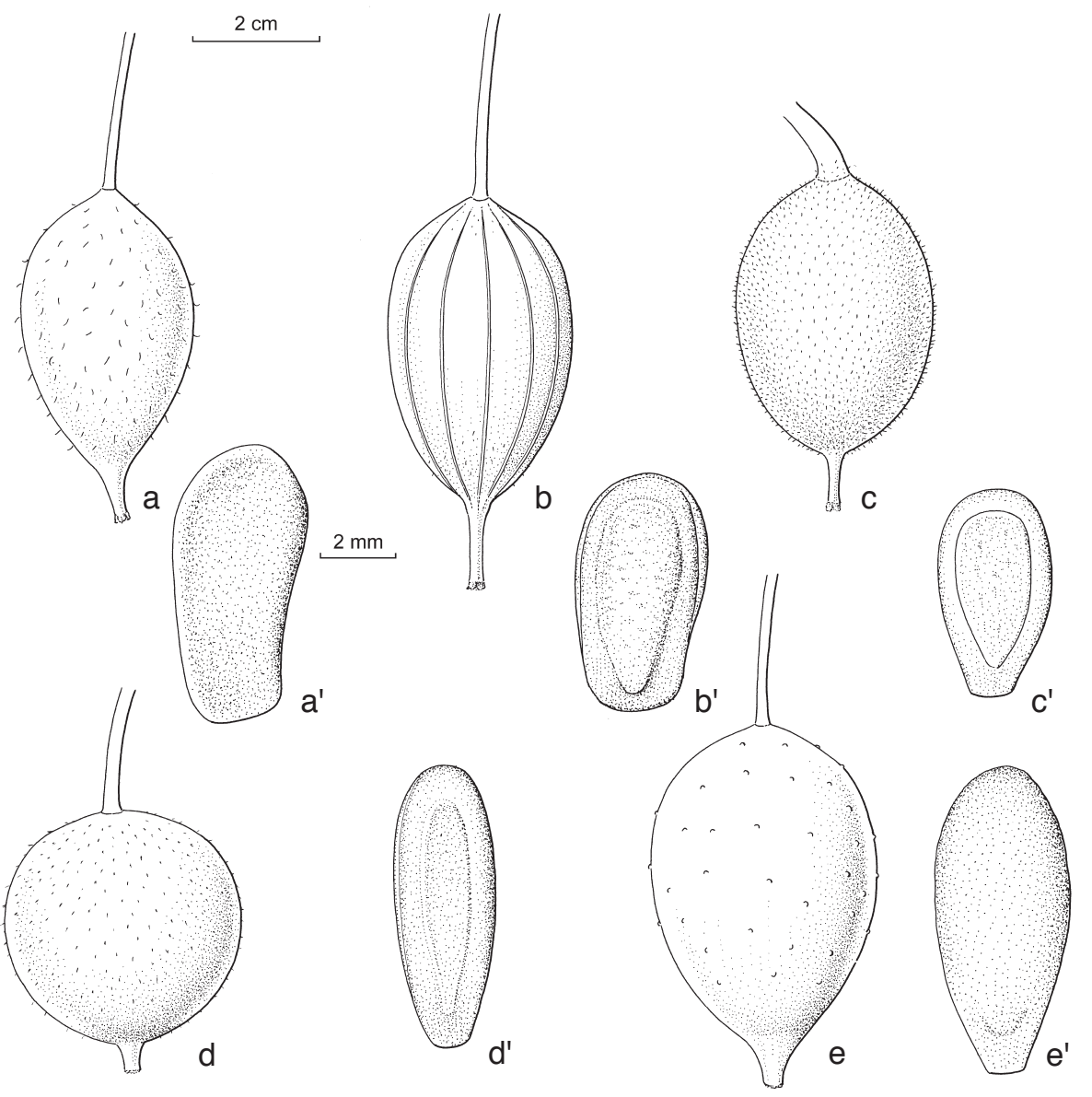

Fig. 1. Fruits and seeds of Gymnopetalum species. a, a'. G. tubiflorum (Wight \& Arn.) Cogn.; b, b'. G. chinense (Lour.) Merr.; c, c'. G. integrifolium (Roxb.) Kurz var. pectinatum W.J. de Wilde \& Duyfjes; d, d'. G. integrifolium (Roxb.) Kurz var. integrifolium; e, e'. G. orientale W.J. de Wilde \& Duyfjes (a: Herb. d'Alleizette 2613; b: De Wilde \& Duyfjes 21719; c: De Wilde \& Duyfjes 21693; d: Pruesapan et al. KP-74; e: Verheijen 3819).

yellow inside; sepals linear, rarely \pm lobed, $6-9 \mathrm{~mm}$ long, spreading to recurved, green; petals obovate, short-clawed, $20-30$ by $12-15 \mathrm{~mm}$, indistinctly veined, somewhat hairy, yellow at base; stamens inserted $12-15 \mathrm{~mm}$ below receptacle throat, filaments short, synandrium $9-10$ by c. $3.5 \mathrm{~mm}$, deeply included, connectives not enlarged; disc (pistillode?) short, 3-lobed. Female flowers: perianth as in male flowers; pedicel $0.5-2(-4) \mathrm{cm}$ long; ovary narrowly ellipsoid, $10-12$ by $2.5-4 \mathrm{~mm}$, pubescent, (faintly) 10-ribbed; style 18-20 mm long, stigmas 4-6 mm long, included; disc low, \pm 3 -lobed, staminodes absent. Fruits broadly fusiform, $2.5-5$ by $1.5-3 \mathrm{~cm}$, beaked by receptacle remnant, orange-red, glabrescent, sharply 10-ribbed, pulp greenish (brown); fruiting pedicel $1-4 \mathrm{~cm}$ long. Seeds numerous, oblong, \pm compressed, $7-8$ by $2-3$ by $1.5 \mathrm{~mm}$, with marginal groove, faces not ornamented. 


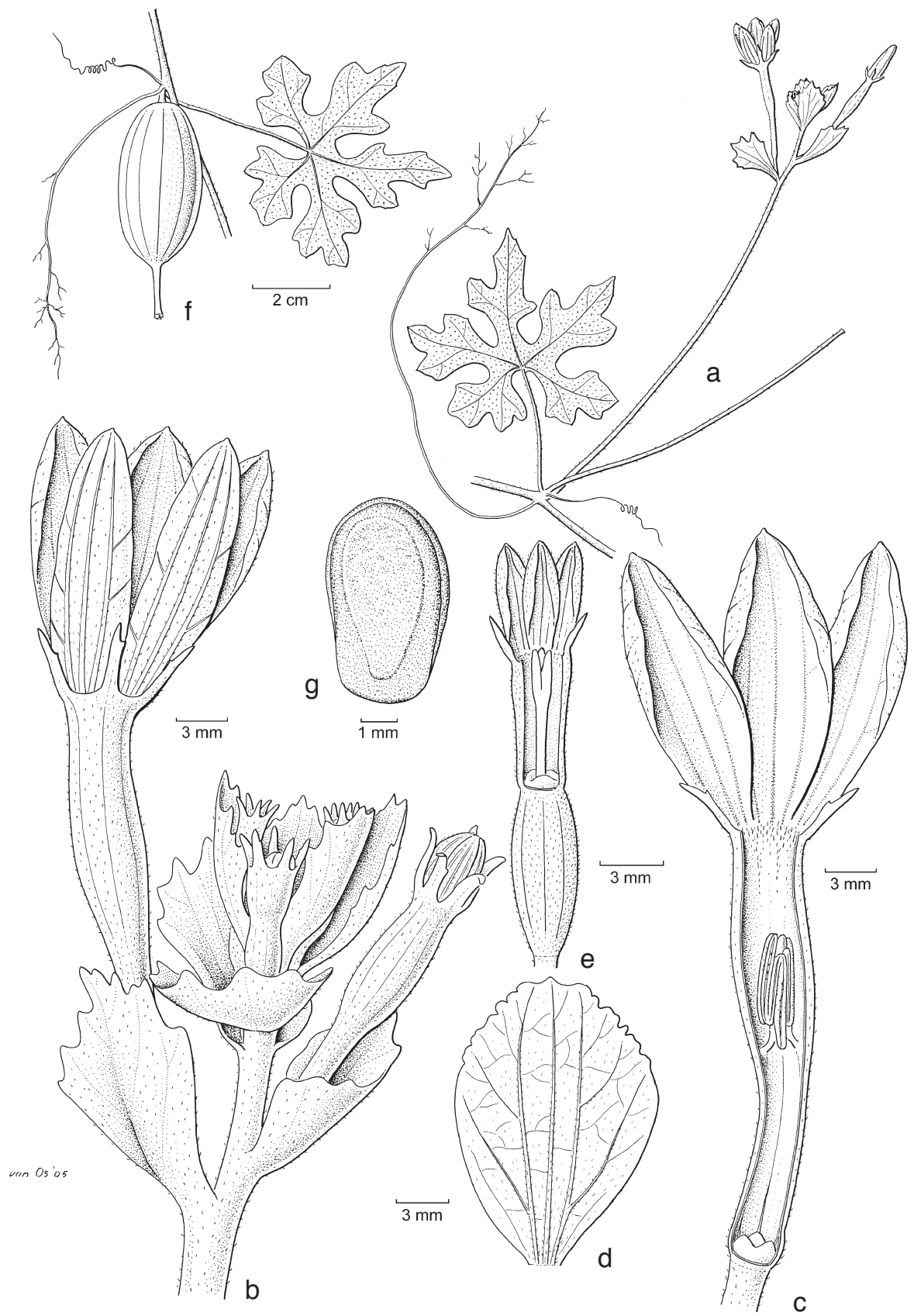

Fig. 2. Gymnopetalum chinense (Lour.) Merr. a. Node with male inflorescence, note persistent pedicel of previous co-axillary male flower; b. apex of male raceme; c. male flower, opened, showing 3-lobed disc at the bottom of the receptacle-tube; d. unfolded petal; e. female flower bud, opened, showing disc at the bottom of the receptacle-tube; $\mathrm{f}$. node with mature fruit; g. seed (a, f, g: De Wilde \& Duyfjes 21719; b-e: De Wilde \& Duyfjes 21722, both from Bali). 
Distribution - Widespread; north-eastern part of India, China, through Indochina, east to Sumatra, Peninsular Malaysia, Borneo, Java, Philippines, Celebes, Lesser Sunda Islands east to Flores.

Habitat \& Ecology - Forest edges, clearings, scrub, in hedges and in open fields; at $0-1000 \mathrm{~m}$ altitude; flowering and fruiting throughout the year.

Note - The flowers of $G$. chinense open at night and are wilted the following morning.

\section{Gymnopetalum integrifolium (Roxb.) Kurz}

Gymnopetalum integrifolium (Roxb.) Kurz (1871a) 58; (1871b) 295; C. B. Clarke (1879) 612; Cogn. \& Harms (1924) 179; Chakrav. (1959) 60; Keraudren (1975) 100, f. 17; A. M. Lu \& Zhi Y. Zhang (1986) 214; P.H. Hô (1991) 722, f. 2004; S.K. Chen (1995) 347; Philcox (1997) 16. - Cucumis integrifolius ('integrifolia') Roxb. (1832) 724; (1978) f. 23. - Trichosanthes integrifolia (Roxb.) Kurz (1877) 99; Cogn. (1881) 386, non Thwaites. - Type: Wallich Cat. 6730 (K-W), Burma.

Trichosanthes scabra Lour. (1790) 589; Gagnep. (1921) 1047; Merr. (1935) 381. - Type: †, CochinChina.

Gymnopetalum leucostictum Miq. (1856) 680; Backer (1964) 302. - Lectotype (here chosen): Junghuhn s.n. barcode L0589693 (L) Java, Weltevreden.

Scotanthus weberi Naudin (1866) 26. - Gymnopetalum weberi (Naudin) Cogn. (1881) 394; Gagnep. (1921) 1053. - Type: cultivated from seeds sent by Weber from Cochin-China to Paris (P?).

Gymnopetalum monoicum Gagnep. (1918) 373; (1921) 1052; Cogn. \& Harms (1924) 180. — Lectotype (here chosen): Balansa 4020 (P), Vietnam (Tonkin).

Gymnopetalum leucostictum Miq. var. grandiflorum Hochr. (1934) 289. - Type: Hochreutiner 2331 (holo G; iso L).

Gymnopetalum integrifolium auct. non (Roxb.) Kurz: A.M. Lu \& Zhi Y. Zhang (1986) 214, f. 55: 8-10; S.K. Chen (1995) 347, f. 90: 6-8 (= G. integrifolium (Roxb.) Kurz var. penicaudii (Gagnep.) W.J. de Wilde \& Duyfjes).

Climbing or creeping, and rooting at the nodes, to $5 \mathrm{~m}$ long, stem (densely) long grey or brownish hairy; monoecious, often seemingly dioecious. Probract lanceolate, acute, entire or (deeply) 2- or 3-lobed, (1-) 1.5-2.5 cm long, sometimes absent, green-yellow, late-caducous. Tendrils simple or unequally 2-branched near the base. Leaves: blade circular, or reniform, or broadly ovate in outline, or 5-angular, 2-11 cm diam., base deeply cordate, apex rounded or subacute, margin entire, finely dentate-mucronate or \pm coarsely lobulate or wavy-dentate; nerves 5-palmate, reticulation distinct below; blade subglabrous above, densely coarse-pubescent below, at least on the veins, when fresh bullate above; glands absent; cystoliths in older leaves present; petiole 1-5 $\mathrm{cm}$. Male flowers: solitary or in bracteate racemes; bracts 1-2 cm long, lobed, base cuneate, sessile; flowers densely grey (to brown) pubescent; pedicel $2-12 \mathrm{~cm}$ long for solitary flowers, $1(-2) \mathrm{cm}$ long in the racemes, persistent, at apex faintly articulate; receptacle-tube (strongly) narrowed below insertion of stamens, $15-20(-30)$ by $6-7$ (at throat) $\mathrm{mm}$, outside and inside pubescent, throat inside yellow; sepals narrowly triangular, lanceolate, entire or \pm lobed, recurved, (4-)5-8 mm long, green; petals obovate, \pm clawed, c. 2 by $1.5 \mathrm{~cm}$, distinctly veined; stamens inserted c. $10 \mathrm{~mm}$ below throat; filaments $2-2.5 \mathrm{~mm}$ long, \pm glabrous, synandrium $8-12$ by $2-2.5 \mathrm{~mm}$, connectives not enlarged, apex of synandrium flat, narrow, hairy, bright yellow when fresh; disc consisting of 3 short linear bodies adnate to base of the tube. Female flowers: solitary, resembling male flowers; pedicel $1-3 \mathrm{~cm}$ long; ovary ellipsoid, $8-10$ by $6-7$ 
$\mathrm{mm}$, long-pubescent; receptacle-tube cylindrical, c. 10 by $5 \mathrm{~mm}$; style $7-10 \mathrm{~mm}$ long, stigmas erect, c. $2 \mathrm{~mm}$ long, \pm included; disc at base of the tube, very low and minute (nectariferous?) or absent; staminodes 3, minute, inserted slightly above base of the tube. Fruits short ellipsoid or globose, (2-)3-4 cm long, (orange-)red, at first sparsely hairy, later on glabrous; fruiting pedicel $1-3(-5) \mathrm{cm}$ long. Seeds numerous in dark green pulp, (ellipsoid-)oblong, \pm compressed, $6-9$ by $2.5-3$ by $1.5-2 \mathrm{~mm}$, faces small, almost smooth, demarcated by groove from broad, rounded margin.

Distribution - Widespread, with 2 varieties. India, Sri Lanka, S China, south-east to the Philippines and Lesser Sunda Islands east to Sumbawa; not known from Sumatra and Borneo.

Habitat \& Ecology — Roadsides, disturbed places; at 0-1000 m altitude; flowering and fruiting throughout the year.

Notes -1 . The watery slimy blackish pulp enveloping the seeds does not taste bitter.

2. The presence of a male raceme in collections from Java appeared much less frequent in G. integrifolium (only c. $20 \%$ ) as compared to those in G. chinense (c. $60 \%)$.

\section{KEY TO THE VARIETIES}

1a. Bracts of male raceme (irregularly) shallowly or deeply few- or many-lobed or \pm irregularly narrowly laciniate. Fruits globose $\ldots \ldots \ldots \ldots \ldots \ldots \ldots \ldots$

b. Bracts of male raceme regularly \pm fine-laciniate in upper half. Fruits ellipsoid. E Java ....................... var. pectinatum

2a. Leaves subentire; subcircular in outline, margin entire or shallowly dentate. Male sepals entire or shallowly few-lobed. - Widespread . . . . . a. var. integrifolium

b. Leaves \pm 5 -angular or 3-5-lobed to c. 1/3 of its length; (sub) ovate in outline, margin (irregularly) coarsely dentate. Male sepals long and narrowly lobed. - Hainan c. var. penicaudii

a. var. integrifolium - Fig. 1d, 3, 4c-e

Leaf blade subcircular in outline or 3-5-angular, margin entire or shallowly dentate. Bracts of male raceme variously rather few-lobed. Sepals narrow-triangular, lanceolate, entire or shallowly few-lobed. Fruits (sub) globose, 2-3(-4) cm diam., glabrescent.

Distribution - As the species, but possibly not in China.

Note - Puudjaa 83 (Thailand) has female flowers in a short raceme.

\section{b. var. pectinatum W.J. de Wilde \& Duyfjes, var. nov. - Fig. 1c, 4a, b}

A varietate typico in bracteis masculinis regulariter anguste laciniatis, fructibus ellipsoideis distinctus. - Typus: W.J. de Wilde \& Duyfjes 21692 (L), E Java.

Leaf blade subcircular or angular in outline, margin (sub)entire. Bracts of male raceme with upper margin regularly, finely, densely laciniate. Sepals subentire or shallowly few-lobed. Fruits ellipsoid with obtuse apex, c. $4 \mathrm{~cm}$ long, finely hairy, not ridged.

Distribution - E Java; known only from the type. 


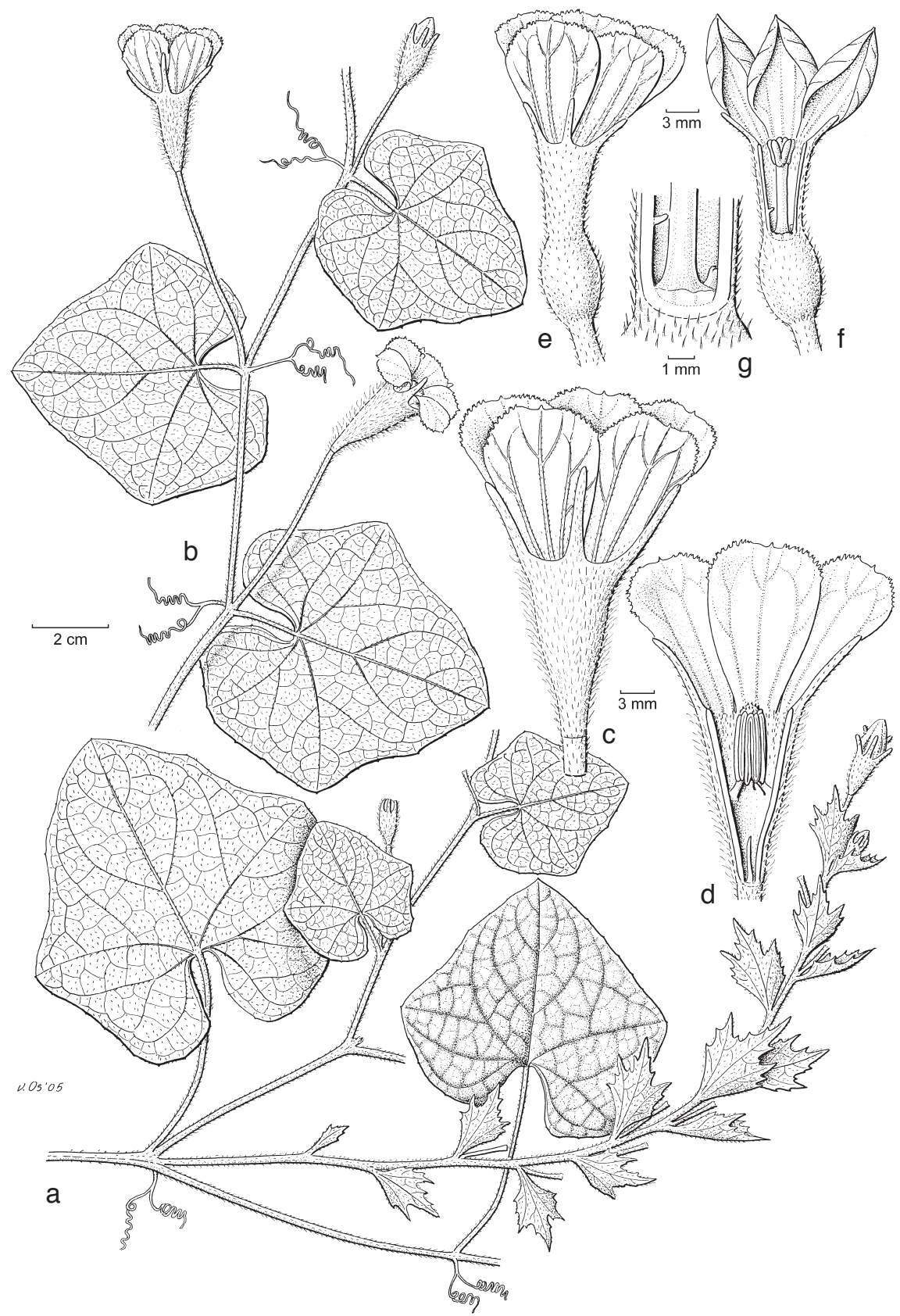

Fig. 3. Gymnopetalum integrifolium (Roxb.) Kurz var. integrifolium. a. Twig with one male raceme, and one solitary male flower in bud; b. twig with solitary male flowers; c. male flower; d. male flower opened; e. female flower; f. female flower opened; g. detail of female flower showing base of style with traces of staminodes at disc (a: Phonsena, De Wilde \& Duyfjes 3515; b: d'Alleizette s.n., barcode L0589688; c-g: De Wilde \& Duyfjes 22269). 


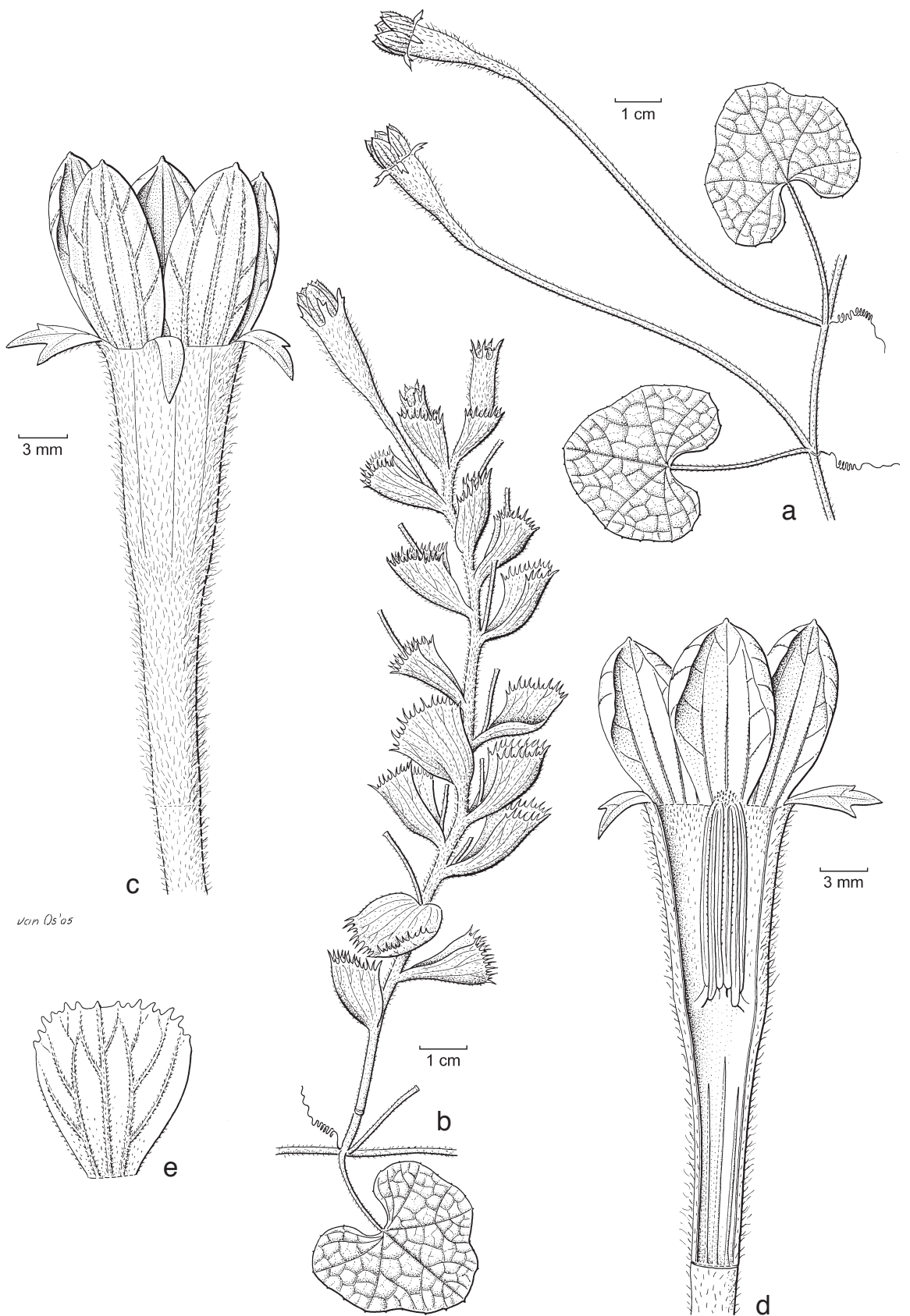

Fig. 4. Gymnopetalum integrifolium (Roxb.) Kurz var. pectinatum W.J. de Wilde \& Duyfjes. a. Portion of twig with solitary male flowers; b. node with male raceme. - Gymnopetalum integrifolium (Roxb.) Kurz var. integrifolium. c, d. Male flower from outside and opened respectively, note the disc composed of 3 linear bodies; e. unfolded petal (a, b: De Wilde \& Duyfjes 21692, type; c-e: Murata, Fukuoka \& Sukasdi J1421). 
Habitat \& Ecology - Among grasses on sawah-dike on clay soil; at sea level.

Note - The status of var. pectinatum is unclear. The finely incised male bracts give the plant a very distinct aspect. The ellipsoid fruit is unique and suggests a relationship with G. chinense; the fruit in the latter species is ridged, with a tapered apex. Possibly var. pectinatum is of hybrid origin.

c. var. penicaudii (Gagnep.) W.J. de Wilde \& Duyfjes, comb. nov.

Gymnopetalum penicaudii Gagnep. (1918) 374; (1921) 1050, f. 17: 1-4. - Lectotype (here chosen): Pénicaud 43 (P), Hainan.

Gymnopetalum integrifolium auct. non (Roxb.) Kurz: A.M. Lu \& Zhi Y. Zhang (1986) 214, f. 55: 8-10; S.K. Chen (1995) 347, f. 90: 6-8.

Leaf-blade \pm 5 -angular or lobed to c. 1/3 of its length, (sub)ovate in outline, margin coarsely dentate. Bracts of male raceme \pm irregularly narrowly laciniate. Sepals oblong, usually with some narrow and long side-lobes. Fruits globose, c. $2.5 \mathrm{~cm}$ diam., glabrescent.

Distribution - Hainan; possibly a wider distribution in S China.

\section{Gymnopetalum orientale W.J. de Wilde \& Duyfjes, spec. nov. - Fig. 1e, 5}

A Gymnopetalo chinensi in habitu crassiore, receptaculi masculini tubo $3.5-7 \mathrm{~cm}$ longo, sepalis masculinis lonis lateralibus longis, pistillodio absenti distinctus. - Typus: De Wilde \& Duyfjes 21937 (holo L), Indonesia, Lombok.

Climber to $5 \mathrm{~m}$ long, minutely hairy, subglabrescent; stem c. $2 \mathrm{~mm}$ diameter. Probract absent or various in size, (ob)ovate, up to $1 \mathrm{~cm}$ long, irregularly sharp-dentate, glandular. Tendrils (simple or) unequally 2-branched in lower half. Leaves: blade membranous, ovate or subcircular in outline, 6-14 cm diam., usually (3-)5 sharp-angular or (deeply) lobed, base deeply cordate, margin (finely) dentate, petiole and veins minutely scabrid-hairy on both surfaces, blade above scabrous by cystoliths; petiole $2.5-7(-9)$ $\mathrm{cm}$ long. Inflorescences: male flowers either solitary with pedicel 2-6 cm long, or usually a solitary flower co-axillary with a later developing long-peduncled few- to 20-flowered raceme, 10-30 cm long, with the flowers bracteate and (sub) sessile, with a scar and not a persistent pedicel; bracts subpersistent or (later) caducous, rhomboid or ovate in outline, $10-15$ by c. $10 \mathrm{~mm}$, sharply $5(-7)$-angular or -lobed, up to half its length, glandular below, subsessile or with a stipe up to $5 \mathrm{~mm}$ long; rachis $5-20 \mathrm{~cm}$ long, peduncle 5-13 cm long, c. $2 \mathrm{~mm}$ diam.; female flowers solitary. Male flowers: (sub) glabrous, but petals minutely hairy especially on the veins; receptacle-tube 3.5-7 $\mathrm{cm}$ long, tapering, at throat 5-8 mm wide; sepals \pm recurved, lanceolate or longtriangular, 5-15 mm long, in basal portion with few long (linear-oblong) patent lobes to $9 \mathrm{~mm}$ long; petals obovate-oblong, 20-30 mm long, apex 1-2 mm mucronate, margin crenulate-lobate, at base with some fringes to $5 \mathrm{~mm}$ long; stamens inserted c. $15 \mathrm{~mm}$ below the throat in the receptacle-tube, filaments $2-3 \mathrm{~mm}$ long, synandrium $10-12$ by $2-4 \mathrm{~mm}$; disc consisting of 3 elongate, acute, carnose bodies $3-15(-20)$ $\mathrm{mm}$ long, adnate to the basal portion of the receptacle-tube; pistillode absent. Female flowers: pedicel $10-20 \mathrm{~mm}$ long; ovary narrowly ellipsoid, $7-16$ by $2-3 \mathrm{~mm}$, harshly minutely hairy (hairs c. $0.1 \mathrm{~mm}$ long), faintly 6-8-ribbed; receptacle-tube c. $30 \mathrm{~mm}$ 


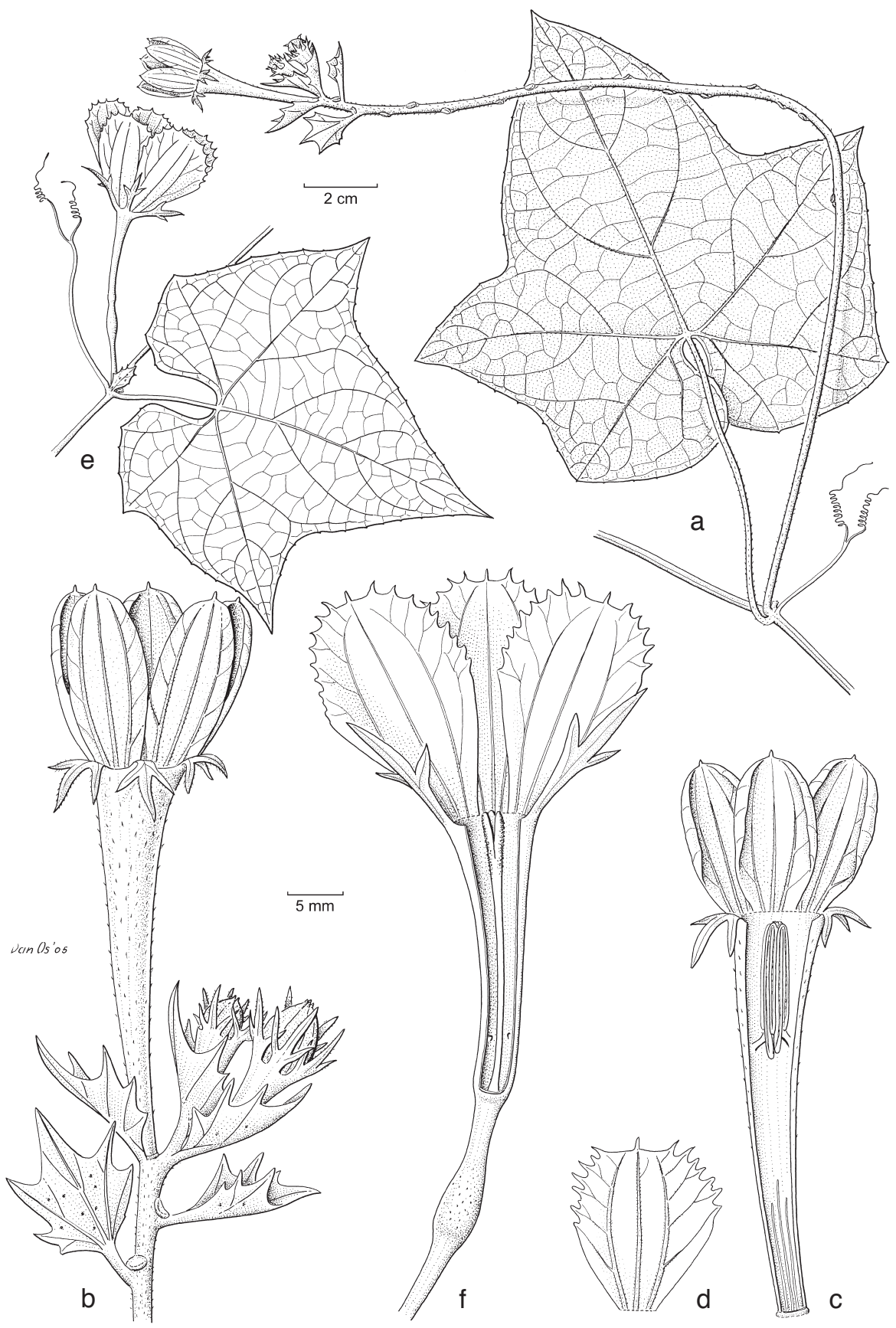

Fig. 5. Gymnopetalum orientale W.J. de Wilde \& Duyfjes. a. Node with male inflorescence; b. apex of male inflorescence; c. male flower, opened, note disc composed of linear thickenings adnate to the receptacle-tube; d. unfolded petal; e. node with female flower, and probract; f. female flower, opened (a-d: Wieringa 1811; e, f: Schmutz 4301). 
long; sepals (5-)10 mm long, with a few side-lobes; petals c. $20 \mathrm{~mm}$ long; style 15(-20) $\mathrm{mm}$ long, stigmas included, c. $10 \mathrm{~mm}$ long, 3-lobed at apex; disc absent; staminodes minute, inserted c. $5 \mathrm{~mm}$ above base of the tube. Fruits (after Verheijen 3819): ellipsoid-fusiform, c. 5 by $3.5 \mathrm{~cm}$, shortly beaked at apex, orange or red, harshly fine-hairy, glabrescent, sometimes with scattered wartlets, faintly ribbed (?); fruiting pedicel 2-7 $\mathrm{cm}$ long. Seeds numerous, long pear-shaped, acutish at one end, $7-8$ by 3.5 by $2.5-3$ $\mathrm{mm}$, not margined, faces very shallowly verrucose-rugose.

Field-notes - Petals white; flowers opening (Flores) between $23.30 \mathrm{~h}$ and $24.00 \mathrm{~h}$, with a spicy odour, visited by midges; flowers (Lombok) still expanded at $12.00 \mathrm{~h}$. Fruits eaten by crows; fruit pulp colour not recorded.

Distribution - E Malesia: Celebes, Lesser Sunda Islands, Moluccas (Seram, Babar Island).

Habitat \& Ecology - Climber in scrub-edge; damp sites; at 25-1500 m altitude; flowering mainly June to January; fruiting in February.

Note - Gymnopetalum orientale resembles $G$. chinense, but the latter is less robust in all parts. The disc in the male flowers, consisting of carnose elongate bodies adnate to the receptacle-tube is similar to those in most of Trichosanthes. Gymnopetalum orientale is reminiscent of Trichosanthes quinquangulata because of its leaf size and shape, its lobed sepals and sometimes \pm fringed petals.

Specimens examined:

De Wilde \& Duyfjes 21937 (male), 21938 (male), both Lombok (both L); Eyma 2496 (male), W Ceram (BO); Forsten 12 (male), Celebes, Tondano (L); Kostermans \& Wirawan 787 (male \& fr.), Flores (K); Schmutz 316 (male), 4761 (male), both W Flores, 4301 (female \& fr.), (all L); Schouten 93 (female), Flores (L); Van Borssum Waalkes 3111 (male \& fr.), Babar Island (BO, K, L; bracts \& sepals very narrowly acuminate); Verheijen 755 (male), 756 (male), 3544 (male), 3819 (male \& fr.), 5382 (male), all Flores (all L); Wieringa 1811 (male), Flores (WAG).

\section{Gymnopetalum tubiflorum (Wight \& Arn.) Cogn. - Fig. 1a}

Gymnopetalum tubiflorum (Wight \& Arn.) Cogn. (1881) 388; Cogn. \& Harms (1924) 178; Philcox (1997) 15. - Bryonia tubiflora Wight \& Arn. (1834) 347. - Gymnopetalum ceylonicum Arn. (1840) 52; (1841) 278, nom. illeg. - Gymnopetalum wightii Arn. var. zeylanicum (Arn.) Trimen (1894) 246. - Type: Rottler s.n. ex Herb. Klein in Herb. Wight Cat. 1118, February 1796 (holo $\mathrm{K}$; iso E, several duplicates), Ceylon, Trincomalee; see note 1 \& 4.

Gymnopetalum wightii Arn. (1840) 52; (1841) 278; Thwaites (1859) 127; C.B. Clarke (1879) 611; Cogn. (1881) 389; Cogn. \& Harms (1924) 179; Trimen (1894) 246, t. 43; Gamble (1919) 530; Chakrav. (1959) 59; C. Jeffrey (1980b) 798. - Type: Wight 1146 (K), Ceylon.

Distribution - S India and Sri Lanka.

Notes - 1. The specimen Wallich Cat. 6724, without precise locality, is possibly a duplicate of the type-collections of Gymnopetalum tubiflorum, as suggested in Wight \& Arnott's (1834) note under Bryonia tubiflora; the there mentioned Wallich Cat. 6703 is a Mukia, whereas Wallich Cat. 6724 (named '?Cucurbita umbellata Wall.', which is a nomen nudum) is the sole representative of G. tubiflorum in Wallich's Catalogue.

According to Philcox (1997: 16), part of the material annotated as Thwaites CP 1625 (in PDA), also originates from Rottler s.n. ex Herb. Klein.

2. We have seen only a limited number of collections from Sri Lanka (see below), but we follow Philcox's (1997) opinion that G. tubiflorum and G. wightii are synonyms. Cogniaux (1881) and Cogniaux \& Harms (1924), following Arnott (1840), recognised 
two species: G. tubiflorum with deeply lobed leaves and the receptacle-tube subglabrous and G. wightii with undivided (or shallowly lobed) leaves and the receptacle-tube densely hairy. The differences mentioned need further study; see also note 3 .

3. Cogniaux (1881) and Cogniaux \& Harms (1924) described the disc glands or pistillodia for G. tubiflorum as 3 in number and $1 \mathrm{~mm}$ long and for G. wightii as single and 3-4 mm long. We examined only male flowers of Thwaites CP 1625 (BO), a specimen with unlobed leaves, the receptacle-tube sparsely hairy and with 3 separate fusiform disc glands, c. $2 \mathrm{~mm}$ long on slender stipes, c. $1.5 \mathrm{~mm}$ long, attached about halfway in the tube, simulating sterile stamens, but it has also a normal androecium in the apical part of the tube. The taxonomic implications of these strongly different forms of disc glands need further study.

4. Gymnopetalum tubiflorum seems rare on the Indian subcontinent. Jeffrey (1980b) and previous authors cited several older collections. We have seen none of these collections, but suspect that some may have originated from Sri Lanka. Likely the specimen sent to Wallich, Wallich Cat. 6724, is part of the original collection by Rottler (Wight 1118) from Sri Lanka as may be inferred from Wight \& Arnott's (1834) note; see note 1. Their identification of Wallich Cat. 6703 is incorrect, as this is a Mukia. Jeffrey (1980b: 806) cites 5 Beddome collections from $S$ India, but we have not seen them. The collection Herb. Wight 314, Courtallem, August 1835 (E) has not been cited by Jeffrey. Some collections cited by Chakravarty (1959) have not been seen by us. Collections from Sri Lanka, where the species apparently is more frequent, are cited by Philcox (1997).

5. Cogniaux (1881) mentions that the flowers from Sri Lanka are yellow, which is possibly erroneous. Trimen (1894) states that they are white, and earlier and recent collectors from Sri Lanka (Philcox, 1997) record the flowers as white, the same colour as in the other species of Gymnopetalum.

Specimens examined:

Herb. d'Alleizette 2613 (fr.), Ceylon (L); s.n. (male) (L); Thwaites CP 1625 (male), (BO); Walker 1738 (male), (E); Wallich Cat. 6724; Wight 314 (male), India, Courtallem (E); (Rottler ex Herb. Klein) Wight 1118 (male \& fr.), Ceylon, Trincomalee, (E, isotype).

\section{EXCLUDED NAMES}

Gymnopetalum calyculatum Miq. (1861) 332; we have not seen the type Amman (= Kurz) from Bangka, but according to its description - tendrils 3-branched, female flowers with 5 spathulate linear bracts - this is Cucurbita moschata.

Two names described from Java, Gymnopetalum piperifolium Miq. (1856) 680, type: Horsfield s.n., and Gymnopetalum horsfieldii Miq. (1856) 680, type: Horsfield s.n., are both Thladiantha cordifolia (Blume) Cogn.

\section{ACKNOWLEDGEMENTS}

We thank NWO (Netherlands Organization for Scientific Research) for a grant enabling us to visit the Bogor Herbarium in 1996. Curators of A, AAU, BK, BKF, BM, BO, BRI, E, K, KEP, L, P, SING, $\mathrm{U}, \mathrm{W}$, and WAG are acknowledged to study Cucurbitaceae in their respective herbaria or sending specimens on loan to Leiden. We also thank Sam Van Hoang (Forestry, Hanoi, Vietnam) and Chue 
Yen Kheng (Singapore) who made an assessment of the variation in G. chinense and G. integrifolium [report not published] during the Training Course of ARCBC in Bogor (2002), which helped determining the status of G. integrifolium var. pectinatum, described in this paper. As usual Dr. Jan-Frits Veldkamp (Leiden) kindly provided the translations into Latin of the diagnoses of the new taxa, and Jan van Os (Leiden) prepared the beautiful drawings.

\section{REFERENCES}

Arnott, G.A.W. 1840. Remarks on the fruit of the natural order Cucurbitaceae. Madras J. Lit. Sci. 12: $48-54$.

Arnott, G.A.W. 1841. On the Cucurbitaceae. J. Bot. 3: 271-280.

Backer, C.A. 1964. In: C.A. Backer \& R.C. Bakhuizen van den Brink Jr., Flora of Java 1: 292-307. Noordhoff, Groningen.

Bentham, G. \& J.D. Hooker. 1867. Genera plantarum 1: 816-841. Reeve \& Co., London.

Blume, C.L. 1826. Bijdragen tot de Flora van Nederlandsch Indië 15: 922-940. Ter Lands Drukkerij, Batavia.

Chakravarty, H.L. 1959. Monograph on Indian Cucurbitaceae. Rec. Bot. Surv. India 17: 1-234.

Chen, S.K. 1995. Gymnopetalum. In: C.Y. Wu, C. Chen \& S.K. Chen (eds.), Flora Yunnanica. 6: 345-351. Science Press, Beijing.

Clarke, C.B. 1879. Cucurbitaceae. In: J.D. Hooker, Flora of British India 2: 604-635. Reeve \& Co., London.

Cogniaux, C.A. 1881. Cucurbitaceae. In: A. \& C. de Candolle, Monogr. Phan. Prodr. 3: 325-951.

Cogniaux, C.A. \& H. Harms. 1924. Cucurbitaceae - Cucurbiteae - Cucumerinae. In: A. Engler, Pflanzenreich 88, iv.275.2: 1-246. Engelmann, Leipzig.

Craib, W.G. 1931. Cucurbitaceae. Florae Siamensis Enumeratio 1: 750-770. Siam Society, Bangkok.

De Loureiro, J. 1790. Flora Cochinchinensis. Lisboa.

De Wilde, W.J.J.O. \& B.E.E. Duyfjes. 2004. The genus Trichosanthes (Cucurbitaceae) in Sabah. Sandakania 14: 5-32.

Don, G. 1834. A general history of the dichlamydeous plants 3: 1-43. Gilbert \& Rivington, London.

Duyfjes, B.E.E. \& K. Pruesapan. 2004. The genus Trichosanthes L. (Cucurbitaceae) in Thailand. Thai Forest Bull., Bot. 32: 76-109.

Endlicher, S.L. 1842. Generum plantarum supplementum secundum: 77. Vienna.

Gagnepain, F. 1918. Cucurbitacées nouvelles de l'Herbier du Muséum. Bull. Mus. Hist. Nat. (Paris) 24: $371-380$.

Gagnepain, F. 1921. Cucurbitacées. Flore Generale de l'Indo-Chine 2: 1030-1095. Masson \& Cie, Paris.

Gamble, J.S. 1919. Flora of the presidency of Madras 1, 3: 526-543. Adlard \& Son, Ltd., London.

Hô, P.H. 1991. Cucurbitaceae. An illustrated Flora of Vietnam 1, 2: 711-728, f. 1974-2020. Mekong Printing, Santa Ana.

Hochreutiner, B.P.G. 1934. Plantae Hochreutineranae. Candollea 5: 287-290.

Jeffrey, C. 1980a. The Cucurbitaceae of Eastern Asia: 1-60. Royal Botanic Gardens, Kew.

Jeffrey, C. 1980b. Further notes on Cucurbitaceae V. The Cucurbitaceae of the Indian subcontinent. Kew Bull. 34: 789-809.

Keraudren-Aymonin, M. 1975. Cucurbitacées. In: A. Aubréville \& J.-F. Leroy (eds.), Flore du Cambodge, du Laos et du Viêt-nam 15: 1-114. Mus. Natl. Hist. Nat., Paris.

Kurz, S. 1871a. On some new or imperfectly known Indian plants. J. Asiat. Soc. Bengal 40: 57-58.

Kurz, S, 1871b. Über einige neue und unvollkommen bekannte indische Pflanzen. Flora 54: 294295.

Kurz, S. 1875. Descriptions of new plants from the Nicobar Islands (including a few from the Andaman Islands). J. Bot. 13: 326.

Kurz, S. 1877. Contributions towards a knowledge of the Burmese flora. J. Asiat. Soc. Bengal 46, 2: $95-106$. 
Léveillé, A.A.H. 1914-1915. Flore du Kouy-Tchéou. Le Mans.

Lu, A. M. \& Zhi. Y. Zhang. 1986. Gymnopetalum. In: A.M. Lu \& S. K. Chen (eds.), Flora Reipublica Popularis Sinica 73, 1: 212-215. Science Press, Beijing.

Merrill, E.D. 1919. Additional notes on the Kwangtung flora. Philipp. J. Sci. 15: 256.

Merrill, E.D. 1935. A commentary on Loureiro's "Flora Cochinchinensis". Trans. Amer. Philos. Soc. 24: 376-381.

Merrill, E.D. 1938. New or noteworthy Indo-Chinese plants. J. Arnold Arbor. 19: 69-70.

Miquel, F.A.W. 1856. Flora Indiae Batavae 1, 1: 652-683. Van der Post, Amsterdam.

Miquel, F. A.W. 1861. Flora van Nederlandsch Indië, eerste bijvoegsel Sumatra: 130-332. Van der Post, Amsterdam.

Naudin, C. 1862. Cucurbitacées cultivées au muséum d'histoire naturelle en 1862. Ann. Sci. Nat., Bot. sér. 4, 18: 159-208.

Naudin, C. 1866. Cucurbitacées nouvelles cultivées au muséum d'histoire naturelle en 1863, 1864 et 1865. Ann. Sci. Nat., Bot. sér. 5, 5: 5-43.

Philcox, D. 1997. Cucurbitaceae. In: M.D. Dassanayake \& W.D. Clayton (eds.), A revised handbook to the flora of Ceylon 11: 8-46. Balkema, Rotterdam.

Ridley, H.N. 1911. An account of a botanical expedition to lower Siam. J. Straits Branch Roy. Asiat. Soc. 59: 15-234.

Roemer, M.J. 1846. Peponiferarum. Synopses Monographicae 2: 1-118. Landes-Industrie-Comptoirs, Weimar.

Roxburgh, W. 1814. Hortus bengalensis. Serampore.

Roxburgh, W. 1832. Flora Indica 3: 701-728. Thacker \& Co., Calcutta.

Roxburgh, W. 1978. Icones Roxburghianae or drawings of Indian plants. Bot. Surv. India, Fasc. 7.

Rugayah. 1999. Trichosanthes (Cucurbitaceae) in Malesia. Dissertation. Institute Pertanian Bogor.

Rugayah \& W.J.J.O. de Wilde. 1997. Trichosanthes L. (Cucurbitaceae) in Java. Blumea 42: 417482.

Rugayah \& W.J.J.O. de Wilde. 1999. Conspectus of Trichosanthes (Cucurbitaceae) in Malesia. Reinwardtia 11: 227-280.

Thwaites, G.H.K. 1859. Enumeratio plantarum Zeylaniae: an enumeration of Ceylon plants: 124-128. Dulau \& Co., London.

Trimen, H. 1894. A Hand-book to the flora of Ceylon 2: 242-262, plates 42-44. Dulau \& Co., London.

Wight, R. \& G.A.W. Arnott. 1834. Prodromus Florae Peninsulae Indiae Orientalis 1: 340-351. Parbury, Allen \& Co., London.

\section{IDENTIFICATION LIST}

1 = Gymnopetalum chinense

$2 \mathrm{a}=$ Gymnopetalum integrifolium var. integrifolium

$2 \mathrm{~b}=$ Gymnopetalum integrifolium var. pectinatum

$2 \mathrm{c}=$ Gymnopetalum integrifolium var. penicaudii

3 = Gymnopetalum orientale

4 = Gymnopetalum tubiflorum

Altmann 142: 1 - Ambriansyah AA 1181: 1 - Amdjah 495: 1 - Amin SAN 127148: 1 - Arifin AA 1123: 1 - Atmodjo 393: 1.

Backer 571: 1; 6510: 2a; 7616: 1; 12118: 1; 16748: 1; 17717: 2a; 23665: 1; 34289: 1; 36215: 1 - Bakhuizen van den Brink Jr. 1260: 1 - Balansa 4020: 2a - Béguin 856: 1 - Beumée A 800: 2a - Bhargava 4689: 1 - Bon 5555: 2a.

Cuadra A 2155: 1 - Cuong 821: 1 - Curtis in Ridley 8350: 1.

De Vogel 3823: 1 - De Wilde 21674: 2a; 21692: 2b; 21693: 2b; 21719: 1; 21722: 1; 21738: 2a; 21819: 1; 21892: 1; 21915: 2a; 21937: 3; 21938: 3; 21948: 2a; 22156: 1; 22166: 1; 22180: 2a; 22269: 2a; SAN 144002: 1 - Den Hoed 961: $2 \mathrm{a}$.

Enoh 274: 1 - Eyma 2496: 3. 
Forbes 228: 1; 1543: 1 - Forsten 12: 3 - Frake PNH 36147: 1 - Fung 20457: 2c.

Garrett 1488: 1.

Hallier 4402: 2a; 4435: 1 - Han SAN 59825: 1 - Helfer 36: 1 - Herb. d'Alleizette 2613: 4 - Hiep NTH 2734: 2a - Hochreutiner 2331: 2a - Holstvoogd 102: 1 - Houwing 793: 1 - How 72613: 2b.

Kievits 2121: 1; 8607: 2a - King's collector 10563: 1 - Kobus 8607: 1 - Kokawa 1550: 1 - Koonthunthod 319: 1 - Koorders 16610: 2a; 21126: 2a; 23000: 2a; 25093: 2a; 27331: 2a; 28242: 2a; 42523: 2a - Kostermans 787: 3; 1108: 1; 1126: 1 - Koyama 15964: 2a.

Larsen 32289: 1; 45382: 2a - Lertkusel 41: 2a - Lörzing 12964: 1.

Maxwell 71-594: 2a; 74-965: 2a; 86-797: 2a; 88-942: 1; 90-851: 1; 90-895: 1; 92-649: 2a; 94-843: 1; 96-1031: 1; 98-273: 2a; 98-950: 1; 98-1143: 2a - Mirmanto EM (98) 23: 1 - Monyrak 172: 2a - Murata J 1421: 2a; T 16200: 2a; T 16607: 2a; T 17005: 1; T 17136: 2a; T 17317: 1; T 37661: 2a.

Nakano 99111: 2a - Niyomdham 967: 1.

Pénicaud 43: 2c - Pereira JTP 700: 1 - Phonsena 3515: 2a; 3976: 1 - Poilane 11322: 2a; 14807: 2a; 19795: 1; 21374: 1; 27163: 2a; 27530: 1; 27546: 2a; 30074: 2a - Pooma 2490: 1 - Postar SAN 106703: 1; SAN 144095: 1 - Posthumus 800: 1 - Pruesapan KP-1: 2a; KP-74: $2 \mathrm{a}$ Puudja 83: 2a.

Ramos BS 36662: 1 - Reinwardt 1766: 1.

Sarip 18:1 - Schmutz 316: 3; 4301:3;4761:3 - Schouten 93:3 - Shimizu T 11778: 2a - Sinclair 9917: 2a; SF 39423: 2a - Sørensson 2119: 2a; 5976: 1 - Spare SF 36704: 2a - Squires 943:1.

Thwaites CP 1625: 4.

Van Balgooy 2311: 1; 2985: 1; 7514: 2a - Van Borssum Waalkes 3111:3 - Van Daalen 393: 1 - Van Niel 3946: 1 - Van Slooten 580: 1 - Van Steenis 2475: 2a - Van Vuuren 95: 2a - Verheijen 755: $3 ; 756: 3 ; 3544: 3 ; 3819: 3 ; 5382: 3 ; 5402: 1$.

Walker 1738: 4 - Wallich Cat. 6711: 1; 6724: 4; 6730: 2a; 6749: 1 - Wichian 314: 2a - Wieringa 1811: 3 - Wight 314: 4; 1118: 4; 1146: 4. 